\title{
Facebook as a Social Support Environment for Older Adults*
}

Facebook como espacio de apoyo social para adultos mayores

Received: 07 June 2015 | Accepted: 09 March 2018

\author{
Fabiola Silva \\ University of Passo Fundo, Brasil \\ ORCID: http://orcid.org/0000-0002-3605-0523 \\ Silvana Alba Scortegagna \\ University of Passo Fundo, Brasil \\ ORCID: http://orcid.org/0000-0002-5100-6459 \\ Ana Carolina Bertoletti De Marchi ${ }^{\mathrm{a}}$ \\ University of Passo Fundo, Brasil \\ ORCID: http://orcid.org/0000-0002-7704-3119
}

a Correspondence author. Email: carolina@upf.br

How to cite: Silvia, F, Scortegagna, S. A., \& De Marchi, A. C. B. (2018). Facebook as a Social Support Environment for Older Adults. Universitas Psychologica, 17(3), 1-11. https://doi.org/10.11144/ Javeriana.upsy.17-3.fsse

\begin{abstract}
The present study investigated the effects of the digital social network Facebook as a source of social support for older adults. Participants included thirteen elderly people, ten women and three men with a mean age of $62.38(\mathrm{SD}=5.28)$, from the state of Rio Grande do Sul - Brazil. For data collection, a sample characterization questionnaire, convoy model of social support and the Scale of Social Support were used. After 36 meetings, the results indicated a significant increase in the structure of the social network via Facebook. The expansion of the network took place in domestic ( $p$ $=0.046)$ and intermediate $(p=0.039)$ circles, which comprise the most intimate and close members. The Feel Respected variable (FR, a part of the functional characteristics of the support network, denoted significant increase $(p=0.007)$. The results indicate that digital networks can be a social support alternative for successful aging.

Keywords

digital social networking; social support; aging; assistance; health.
\end{abstract}

\section{RESUMEN}

Este estudio investigó los efectos de la red social digital Facebook como fuente de apoyo social para adultos mayores. Los participantes eran trece mayores, diez mujeres y tres hombres, con una franja de edad de $62.38(\mathrm{DP}=5.28)$, que vivían en Rio Grande do Sul- Brasil. Para recoger los datos fueron utilizados un cuestionario de caracterización de la muestra, el Diagrama de Escolta y la Escala de Apoyo Social. Tras 36 encuentros realizados, los resultados indicaron un aumento significativo en la estructura de la red social a través de Facebook. La amplitud de la red ocurrió en los círculos interno $(p=0.046)$ y intermedio $(p=0.039)$, los cuales componen los miembros más íntimos y próximos. La variable Sentir Respetado (SR) presentó aumento significativo $(p=0.007)$, integrante de los rasgos funcionales de la red de apoyo. Los resultados indican que las redes digitales pueden ser una alternativa de apoyo social para el envejecimiento exitoso. 
Palabras clave

Redes sociales digitales; apoyo social; envejecimiento; atención; salud.

Social support is characterized by the functional and qualitative dimension of the network of social relations and may be offered by means of help, care or instrumental, economic, social, physical and emotional accompaniment, exercised reciprocally or unilaterally. Rodrigues and Silva (2013) emphasize that it is important to distinguish between "social network" and "social support". The term social network is used by several authors to name a group of people who have some form of contact between each other. While, for social support to be characterized, the individual's interaction with the network needs to occur, enabling an exchange system between these parties to satisfy a part of their..."social needs.

The social support network is made up of sources which can increase the feeling of wellbeing of the elderly, improve their health, reduce the chances of developing cognitive decline, depression and isolation and, thus foreseeing the risk of premature death (Cornejo, Favela \& Tentori, 2010; Grieve, Indian, Witteveen, Tolan, \& Marrington, 2013; Myhre, Mehl \& Glisky, 2016). Studies show that the development of social isolation and loneliness in the elderly contributes to declining health, both physical and mental (Bell et al., 2013; Canesqui \& Barsaglini, 2012; Paula-Couto, Koller, Novo \& Soares, 2008; Ferreira, Silveira, Noto \& Ronzani, 2014; Brito, Costa \& Pavarini, 2012).

It should be noted that the social network goes through periods of change over the life cycle (Bell et al., 2013; Gibson et al., 2010), which an contribute to the occurrence of social isolation and loneliness (Gibson et al., 2010). This is because as adults get to an advanced age, keeping the social connection can become more difficult due to limitations in mobility, chronic illness and other age-related issues, thus reducing the physical connection with friends, family and community. For these reasons, social media seem to begin to play a more active role in keeping this population socially connected (Bell et al., 2013).
Over the past decade, the use of social networks among Internet users aged 65 and over has been growing. By mid-2012 a third (34\%) of these users, according to the study for Pew Internet and American Life, used social networking sites, and 68\% used Facebook (Zickurh \& Madden, 2012). Therefore, it becomes increasingly imperative to understand the influence of the use of social media on older adults.

Therefore, social networks can take on the role of fostering interpersonal interactions. Such a function may comprise qualitative and behavioral aspects of social relations, as a system of exchanges between receiving and providing support, being it divided into four types (Rosa, Benicio, Alves \& Lebrão, 2007; Rodrigues, 2010): (1) emotional support, which involves the person feeling loved, wanted and respected through exchange of experiences and conversations that generate affection; (2) instrumental or material support, which happens through the actions and concrete assistance, physical or material, provided to others, such as financial aid or practical work; (3) information support, which involves guidance, information, advice and tips that help people to cope better with tasks and problems to be solved; (4) positive social interaction, which refers to the availability of people with whom one can have fun and relax.

In order to measure the function and structure of the support network, Kahn and Antonucci (1980) created the Convoy Model of Social Support. For the authors, support networks should be analyzed from the perspective of its symmetry, stability, connectivity and homogeneity, as well as their characteristics and frequency of interactions between the members and the type of support received and provided.

The Convoy Model of Social Support was used in the studies of Paula-Couto et al. (2008), Brito et al. (2012) and Lampert (2009). In the first two, the objective was to evaluate the structure and function of the support network of normal elderly individuals with cognitive changes. Lampert's study (2009) investigated whether the support network and resilience interfere with psychological, neuroendocrine 
and immunological disorders of chronic stress. In all three studies, the results showed that the networks investigated were composed predominantly by members who are in the first circle (internal), family members, and that the members who provided support were mostly children, female, with contact on a daily basis with the elderly and long-term relationships. For Brito et al. (2011) and Lampert (2009), the elderly described that they received and provided support in a reciprocal form with members who are in the first circle for being more intimate relationships. However, reciprocity was not observed in the study by Paula-Couto et al. (2008), where participants described having provided more support than they received from the members cited in the first circle.

Still, in the three studies, it was observed that the support was derived mainly from family members who lived near the elderly. In this context, the physical distance is an inhibiting factor of interpersonal relationships established in the network. Thus, digital social networks like Facebook become allies in establishing distance interactions. Authors believe that digital social networks have the potential to strengthen the social network for the elderly, by approximating and enabling the expansion of family relationships, increasing the network of friends, as well as promoting social support, approximating generations and restoring the lost relationships (Carvalho, Tarallo, Batistoni \& Cachioni, 2014; Páscoa \& Gil, 2012; Cornejo et al., 2010; Gibson et al., 2010).

Carvalho et al. (2014) sought to identify the impacts and repercussions in a group of 20 elderly participants of a workshop on digital inclusion. The results showed a positive change in the perception of Facebook by the elderly after intervention, being considered as a tool for building friendship ties, facilitating communication for the establishment of new social support networks, in a virtual mode.

Páscoa and Gil (2012) explored the contribution of the Facebook social network in promoting active aging. 13 elderly individuals attended a computer workshop. As a result, the authors found that most students expressed opinions in favor of the use of digital tools to combat isolation, promote socialization, being understood also as a form of leisure and entertainment. In addition, the generations are brought together, between grandparents and grandchildren, allowing the reunion of people who had lost touch. The survey found that Facebook is a digital tool with the potential to increase self-esteem and promote successful aging.

Cornejo et al. (2010) investigated whether nine elderly people maintained emotional ties with 32 family members through Facebook for four months. The results showed that the communication established through Facebook with children and grandchildren who live far helped the elderly to not feel dissociated from the family group. The authors estimate that Facebook has the potential to strengthen the social network for the elderly, facilitating the emotional social support and access to information resources.

Gibson et al. (2010) investigated the interest and feelings related to digital social networks with the elderly. The results showed that social networks of these elderly on Facebook consisted primarily of relatives and friends, got before the work reform or their previous social life and new friends made during retirement. The participants felt that Facebook assists in the contact with family and friends, including those who are physically distant, but also those who are closebut cannot maintain frequent personal contact due to the busy day-to-day work life. Myhre et al. (2016), on the other hand, allowed participants to use Facebook to connect only with other research participants, not with friends or family. The results did not show significant changes in social support and social integration. According to the authors, some elderly may have been unable to form meaningful links with other participants of the research, which did not allow the expansion of the social network.

In a previous study, Bell et al. (2013) sought to examine the relationship between the use of Facebook, social satisfaction, and confidence with technology, using a more representative sample of 142 older adults with an average age of 
72 years. Fifty-nine participants (42\%) identified themselves as Facebook users and 83 participants (58\%) were not Facebook users. Facebook users scored higher on ratings of social satisfaction and confidence with technology compared to nonusers. Preliminary results suggest that many older adults use Facebook, especially to stay connected with the family.

Even in the face of the divergence of literature findings, some studies have shown that social networks can provide a promising path to increase social connections in the elderly (Bell et al., 2013; Grieve et al., 2013). According to Bell et al. (2013), this is mainly because it allows the connection with family and friends and according to Grieve et al. (2013), the social experience with the use of Facebook is similar to that obtained in face-to-face relationships.

In view of these elements, which reveal inconsistent findings related to the benefits of Facebook, and considering the increasing use of this technology among the elderly, and the greater growth of the global population, it is necessary to develop studies that address these issues in this part of the population. Therefore, the aim of this study was to investigate the effects of the digital social network Facebook as a source of social support for older adults.

\section{Method}

\section{Participants}

The sample consisted of 13 elderly, selected by non-probabilistic sampling for convenience from living spaces frequented by the elderly, participants were members of the digital inclusion group in the Coxilha city - RS - Brazil. The inclusion criteria were: age greater than 50 years, be literate, have general satisfactory physical and mental health conditions to understand and respond to the instruments in the stages of pre-intervention, intervention, postintervention, and no prior access to digital social networks. There were no dropouts along the research.

\section{Instruments}

The instruments used for data collection were: a) Sample characterization questionnaire: elaborated by the researchers of this study in order to obtain demographic data and health and illness information. In addition to checking the knowledge about the digital social networks and the criteria for inclusion and exclusion of the sample, this instrument has questions about identification data (e.g. address, occupation, type of housing), family composition (e.g. name, age, kinship), health situation (e.g. type of disease, how much disease time span) and general information.

b) Convoy Diagram: in order to identify structural and functional aspects of social networking. Proposed by Kahn and Antonucci (1980) and adapted by Paula-Couto et al. (2008) for the Brazilian version to know the social network elderly.

c) Social Support Scale: In order to investigate the role of social determinants in health and morbidity patterns of behavior. Developed by Sherbourne and Stewart in 1991 and translated and adapted to Portuguese by Griep, Chor, Faerstein, Werneck and Lopes (2005). In a construct validity study, the scale presented Cronbach's alpha coefficient equal to or greater than 0.83 for all dimensions. It was also observed that there were no changes in the internal consistency of the dimensions, in case any of the items were excluded (Griep et al., 2005).

\section{Procedures}

The project was approved by the Research Ethics Committee under protocol number 999894. Elderly people who agreed to participate signed the Free and Informed Consent Form. Finally, the data were collected in six months, in three stages, namely:

1. Pre-intervention: sample characterization questionnaire was applied individually by the researcher, Convoy Diagram and the Scale of

| Universitas Psychologica | V. i 7 | No.3 | 2018 | 
Support were used. Data collection lasted about one and half hours, being held in homes or at the institution's premises, according to the participant's preference.

2. Intervention: took place through Facebook in the months from May to September 2014. Thirty-six meetings were held twice a week, lasting two hours each. Before starting the activities on Facebook, the group received beginner classes on the use of computers. So with the help of a computer instructor, the program occurred as follows: i) fourteen meetings aimed at the initial use of computers; ii) twenty-two meetings on the use of Facebook, in which the group "Melhor Idade Coxilha" was created, facilitated by the researcher, it was aimed at promoting the informational social support on issues relevant to active aging and social rights of the elderly, as well as contents of humor and reflection on life. Participants were mobilized to interact so as to have exchanges, share ideas, knowledge and experiences proactively. In this space, videos, news links on healthy eating, exercise, myths about aging, social rights of the elderly, disease prevention, reflections, music, cartoons, recipes, messages, poems, readings indications, among others were published.

3. Post-intervention: Convoy Diagram and the scale of support were reapplied, following the same procedures.

\section{Data analysis}

For the analysis of the data from the characterization questionnaire of the sample, descriptive statistics were used, and the Wilcoxon test, with a level of significance of 5\%, was used for the Escort Diagram.

\section{Results}

First, the characterization of the participants is presented and the pre- and post-intervention Convoy Diagram results, regarding structure and function too. The results obtained with the scale of social support will then be described.

Table 1

Socio-demographic characteristics of participants ( $n$ $=13$ )

\begin{tabular}{|llr}
\hline & Sociodemographic characteristics & Frequency \\
\hline Gender & Male & $3(30 \%)$ \\
& Female & $10(70 \%)$ \\
\hline Marital status & Married & $11(80 \%)$ \\
& Widowed & $2(20 \%)$ \\
\hline Schooling & Elementary School Incomplete (4th to 5th grade) & $11(80 \%)$ \\
& Elementary School Completed & $1(10 \%)$ \\
& High School Completed & $1(10 \%)$ \\
\hline Occupation & Retired & $11(80 \%)$ \\
& Homebody & $2(20 \%)$ \\
\hline \multirow{2}{*}{ Income } & 2 Minimum wages & $8(61.53 \%)$ \\
& 3 Minimum wages & $1(7.69 \%)$ \\
& 5 Minimum wages & $4(30.76 \%)$ \\
\hline Age in years & Mean $(S D)$ & $62.38(5.28)$ \\
\hline
\end{tabular}

Table 1 shows that the average age of participants was 62.38 years $(\mathrm{SD}=5.28)$, the minimum being 57 and the maximum 73 years. The group has similar characteristics in terms of the predominance of older adults range, being married, retired and low socioeconomic and educational levels, and different in terms of gender. Among the participants, six had already had prior contact with the computer before the intervention, and eight had it at home.

\section{Support Network}

As for the quantitative variables of the support network, there was a statistically significant increase in its size. This network expansion occurred in the first and second circles, which are the main ones for having the most intimate and close relationships, according to Table 2 . 
Table 2

Description of the support network structure and the size variables, age, time relationship and distance from the residence

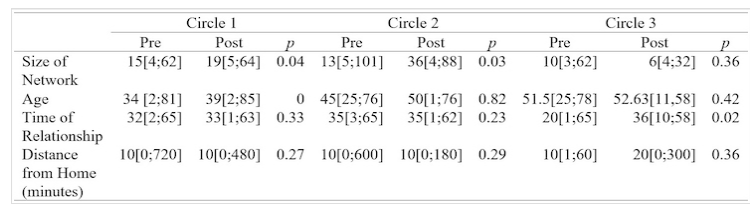

Note: Values expressed in median [minimum; maximum]

It can be seen in Table 2 that the age of the network's members ranged between 1-85 years in three circles, so $49 \%$ of the members remained the same and $51 \%$ were no longer part, and, among these, in the first circle, 65\% of people remained and $35 \%$ were changed; in circle two, $38 \%$ were members who had remained the same and $62 \%$ were removed; while in the circle three, only $18 \%$ remained the same and $82 \%$ of the members had left the network. The time of relationship among them was high and the distance between the residences changed considerably according to each circle. However, it should be noted that the members of the first and second circles were predominantly farther than the third. Table 3 describes the structure of the support network and the variables gender, type of relationship and often noting that contact with members occurs over daily and weekly basis.

Table 3

Description of the support network structure and gender, relationship type and frequency variables (percentage)

\begin{tabular}{|llrrrrrr|}
\hline \multicolumn{2}{|c}{ Variables } & \multicolumn{2}{c}{ Circle 1 } & \multicolumn{2}{c}{ Circle 2 } & \multicolumn{2}{c|}{ Circle 3 } \\
\cline { 2 - 8 } Gender & Feminine & 60.6 & 54.4 & 48.6 & 69 & 68.2 & 45.5 \\
& Masculine & 39.4 & 45.6 & 51.4 & 31 & 31.8 & 54.5 \\
\hline Type of & Family & 97.2 & 90 & 43.2 & 41.4 & 22.7 & 45.5 \\
relationship & Friends & 2.8 & 10 & 56.8 & 55.2 & 63.6 & 54.5 \\
& Workers of & 0 & 0 & 0 & 3.4 & 13.6 & 0 \\
& Social & & & & & & \\
& policies & & & & & & \\
\hline Frequency & Daily & 53.5 & 46.7 & 37.8 & 20.7 & 50 & 36.4 \\
& Annually & 2.8 & 4.4 & 13.5 & 0 & 0 & 0 \\
& Weekly & 25.4 & 24.4 & 35.1 & 51.7 & 31.8 & 36.4 \\
& Irregularly & 5.6 & 4.4 & 5.4 & 10.3 & 9.1 & 27.3 \\
& Monthly & 12.7 & 20 & 8.1 & 17.2 & 9.1 & 0 \\
\hline
\end{tabular}

Table 3 shows a predominant number of women in the three circles. The most observed relationship type between network members is that of the family order, as follows: spouse, children (as), grandchildren, siblings, in-laws, uncles and aunts, nephews and nieces, daughters and sons in law. Table 4 shows the function of the variables of the support network.

\section{Table 4}

Description of the functions of the Social Support Network

\begin{tabular}{lrrr}
\hline Function & \multicolumn{1}{c}{$\begin{array}{c}\text { Pre- } \\
\text { intervention }\end{array}$} & $\begin{array}{c}\text { Post- } \\
\text { intervention }\end{array}$ & \multicolumn{1}{c}{$\boldsymbol{p}^{*}$} \\
\hline CCI & $6[1,19]$ & $5[1,18]$ & 0.66 \\
TMI & $4[1,24]$ & $4[2,11]$ & 0.85 \\
SR & $32[3,193]$ & $78[14,193]$ & 0 \\
CSD & $4[2,21]$ & $4[2,18]$ & 0.08 \\
CTD & $2[0,10]$ & $3[1,18]$ & 0.2 \\
CSS & $3[1,9]$ & $2[1,12]$ & 0.38 \\
\hline
\end{tabular}

Note. CCI: Confiding things that are important; TMI: Be reassured and stimulated in times of uncertainty; SR: Feel Respected; SCD: Be taken care of in case of a disease situation; CTD: Talk when you're sad nervous or depressed; CSS: Talk about one's own health. Unit: people. Values expressed in median [minimum; maximum]. *Wilcoxon Test

Regarding the function of the support network (Table 4), only the variable Feel Respected (FR) had a significant difference statistically postintervention. All participants described that they received and provided social support reciprocally from members cited in the support function. Friends and family members present in the first circle (internal) were identified as the largest providers of support in six variables. The FR and CSS variables (Talk About one's Health) encompassed friends, doctors and family members who are in the three circles.

\section{Social Support Scale}

Regarding the type of support, statistically significant changes were not obtained after analyzing the data before and after the intervention. Thus, for a better understanding of the changes, the results were evaluated from what decreased, increased or remained the same after the intervention period, as shown in Table 5. 


\section{Table 5}

Percentage description of Social Support Scale $(n=$ 13)

\begin{tabular}{lrrr|}
\hline Support & Decreased & Increased & $\begin{array}{c}\text { Remained the } \\
\text { same }\end{array}$ \\
Material & 21.23 & 13.46 & 67.90 \\
Affectionate & 7.69 & 10.25 & 82.05 \\
Emotional & 19.23 & 21.15 & 59.61 \\
Information & 9.61 & 24.99 & 65.38 \\
Social Interaction & 16.25 & 23.07 & 66.66 \\
Positive & & & \\
\hline
\end{tabular}

Thus, it can be considered that the majority of participants remained the same, receiving the same kinds of support mentioned after the intervention in the digital social networks. The material support was the type of support that decreased the most to some participants postintervention and there was a more significant increase in the support relating to information and positive social interaction after contact with the network.

\section{Discussion}

The purpose of this study was to investigate the effects of digital social networks as a source of social support for older adults. The results support and assert this feature as one of the support networks. The sample characterization data corroborate the literature which indicates that the size of social support networks varies according to gender and external variables. In this study, the majority of the sample consisted of women, of low education and socioeconomic levels.

According to Sousa, Silver and Griep (2010), women have a wider social network and offer more support, since men tend to restrict their contacts to family and participate less in social activities. Moreover, Rosa et al. (2007) show that older adults with low levels of income and education tend to participate less in activities that include social interactions, especially those who were born and raised in a period of difficult access to education, especially women, because the priority was given to men.

Regarding the structure of the support network of the participants, there was a statistically significant increase in the first two circles, showing that there was an increase in the number of network members. These results agree with studies of Páscoa and Gil (2012) and Carvalho et al. (2014), which also found that the use of Facebook has enabled the expansion of family relationships and increased the network of friends. In old age, the social support networks aim to optimize cognitive, physical, social and emotional functioning, with the support groups, where people share emotional closeness, being a secure foundation in aid of health protection (Kahn \& Antonucci, 1980; Antonucci, Birditt \& Akiama, 2009).

For Canesqui and Barsaglini (2012), the increase in the number of network members contributed positively to at least one form of support, and the size of the network is associated with the provision of social support, so that the more restricted social networks, have lower chances of receiving support and having life satisfaction. For Bell et al. (2013), although the support network seems smaller in the elderly, it is richer with people who share some kind of intimacy in their lives, such as family and close friends, something that can contribute to increase social satisfaction and, consequently, reduce the loneliness that causes several diseases. Further, according to the authors, only $13.6 \%$ of the elderly in the study were interested in meeting new people on Facebook, while $88.1 \%$ said they used it to connect with friends and family.

These findings legitimize the results found in this study, which identified a statistically significant one in the increased network result in form of support, the variable "Feel Respected" (FR).

For Rosa et al. (2007) and Rodrigues (2010), the variable Feel Respected (FR) represents the person feeling loved, wanted and valued, through the establishment of exchange of experiences and conversations that generate affection. It is believed that the establishment of exchanges among participants with members of their network, also associated with the sense of capacity for integration into the digital world, made the elderly feel respected and socially valued. To Santiago (2011), digital 
inclusion provides the strengthening of selfesteem, enabling the expansion of the degree of autonomy.

By offering the support that the elderly need, the support networks play an important role to allow the maintenance of social contacts, from which they derive other aspects relevant to sociability in old age. Among them, Neri (2014) notes that opportunities are created for the elderly to feel cared for, loved and valued; giving them assurance that they are integrated into common network and reciprocal relations; thus assisting them in overcoming stressful events and reflection of their own skills that produce meaning and fulfillment. These factors favor the stimulus of feelings and beliefs, preserving selfesteem and favoring motivation.

Another important factor identified in this study, which reinforces the feeling of being respected in the participants, is that after the intervention with Facebook, the five participants who had no computer at home, acquired one. This shows how much the participants were motivated, confident with the new skills and felt the need to continue interacting and communicating with their network. Part of this result supports Bell et al. (2013), especially when they demonstrated that elderly Facebook users reported more confidence in their ability to learn and use the new technology.

With regard to the emotional support of the Social Support Scale, the results showed no significant changes. It is believed that these results are due to the fact that most of the members of the first circle remained the same before and after the intervention with Facebook. According to Paula-Couto et al. (2008), the relationships of the first circle are identified as being stable, strong and not depending on exercised social roles for their maintenance, being the main sources of support. The members of the first circle and the study participants had already established exchanges support before the use of Facebook, having more intimate relationships, which according to Rodrigues (2010) and Paula-Couto et al. (2008) serve as protection in the occurrence of negative events, contributing to increase the subjective well-being of the elderly.

In the first circle (internal) more family members were named than friends, and these were identified as the main providers of network support, which occurred in a mutual and balanced way among members. In the results of Paula-Couto et al. (2008), Brito et al. (2012) and Lampert (2009) family also predominated in the first circle, being the main providers of support.

With regard to the time of relationship, the average distance between households, the frequency of contact and the predominant gender of members of the first circle, the results confirm previous findings of Paula-Couto et al. (2008), Brito et al. (2012) and Lampert (2009). In these studies, the distance from home is close for the members of the network, contact is frequent and predominant among females.

In the second circle (intermediate), increase in the number of members of the network was superior to the first, with more friends being cited than family, observing a change of the cited members. These data corroborate the findings of Paula-Couto et al. (2008) which point out that the relations of the second circle are not fully independent and can be related to social roles and therefore can be lost over time.

The third circle showed a reduction in members despite the friends remaining in greater numbers, the number of families doubled compared to pre-intervention, with a major change of the cited members. The data suggest that there was a reallocation of the families of the inner circles to the third circle, in view of the increase in the number of friends in the first circle. These results agree with the Carvalho et al. (2014), who also found that Facebook allowed to build bonds of friendship, emphasizing the importance of these interactions for the formation of new support networks, in the virtual world. In the same direction, the results of Paula-Couto et al. (2008) indicate that the third circle has dependent and limited relationships, maintained by social roles and are therefore unstable and vulnerable.

Regarding the distance between households, it was observed that there was a reduction in 
average minutes of displacement in the three circles. Additionally, members listed in the first two circles are more physically distant from those present in the third circle. This result indicates that more significant family and friends are more distant physically. It was also noted that there was a decrease in daily physical contact with members of the network in the three circles. It is assumed from this result, that daily physical contact was replaced by interactions with the family members and friends whose communication was not facilitated, making Facebook a tool that facilitated the online interaction, as well as increased informational support and positive social interactions. These results confirm previous findings by Cornejo et al. (2010) and Gibson et al. (2010), which show the distance as a provider of news and daily information about their distant relatives.

There are several limitations to the present study. First, the reduced sample number does not allow the generalization of the findings. These results need to be replicated with a more representative sample and with a larger number of elderly men. Secondly, the short period of intervention stands out. For this short period, it is not possible to understand the impact of network support and the long-term impact, especially since it is possible to maintain longterm and autonomous results in the elderly. Therefore, it is suggested, as future work, that a longitudinal study be conducted to improve the research. Nevertheless, it is important to create an appropriate tool for assessing digital social media support for older adults.

\section{Conclusion}

Given the results, it is evident that Facebook can contribute to the occurrence of social support for older adults, especially allowing participants to feel valued and considered socially by their network of relationships. In this sense, it highlights the central role of reciprocity in this stage of life, which can raise self-esteem and prevent feelings of dependence and lack of autonomy.
The study also showed significant results in the structure of social networks, with expansion occurring in the first and second circles, which have the most intimate and close members. It is believed that Facebook may have contributed to the consolidation of family relationships and increased the network of friends and facilitated communication between them and access to news, information, entertainment and leisure. These aspects leverage the increased well-being, helping the elderly to maintain a network of active and stronger social support.

\section{Acknowledgements}

The Brazilian National Council for Scientific and Technological Development (CNPq) for their support.

\section{References}

Antonucci, T. C., Birditt, K. S., \& Akiyama, H. (2009). Convoys of social relations: An interdisciplinary approach. In V. L. Bengston, D. Gans, N. M. Pulney, \& M. Silverstein (Eds.), Handbook of theories of aging (pp. 247-260). New York, NY, US: Springer Publishing Co. Retrieved from http://psycnet.apa.org/record/2009-01 257-014.

Bell, C., Fausset, C., Farmer, S., Nguyen, J., Harley, L., \& Fain, W. B. (2013). Examining social media use among older adults. In Proceedings of the 24th ACM Conference on Hypertext and Social Media (pp. 158-163). Paris, France: ACM. Retrieved from http:// doi.acm.org/10.1145/2481492.2481509

Brito, T. R. P., Costa, R. S., \& Pavarini, S. C. I. (2012). Idosos com alteração cognitiva em contexto de pobreza: estudando a rede de apoio social. Revista Escola Enfermagem USP, 46(4), 906-913. https://doi.org/10.15 90/S0080-62342012000400018

Canesqui, A. M., \& Barsaglini, R. A. (2012). Apoio social e saúde: pontos de vista das ciências sociais e humanas. Ciência E̊ Saúde 
Fabiola Silva, Silvana Alba Scortegagna, Ana Carolina Bertoletti De Marchi.

Coletiva, 17(5), 1103-1114. https://doi.org/ 10.1590/S1413-81232012000500002

Carvalho, G. M., Tarallo, R. S., Batistoni, S.S.T., \& Cachioni, M. (2014). Redes sociais e geratividade: a experiência do programa idosos On-line. Estudo Interdisciplinares Envelhecimento, 19(3), 793-812. Retrieved from http://www.seer.ufrgs.br/index.php/R evEnvelhecer/article/view/40759

Cornejo, R., Favela, J., \& Tentori, M. (2010). Ambient displays for integrating older adults into social networking sites. In G. Kolfschoten, T. Hermann, and S. Lukosch (Eds.), Collaboration and Technology CRIWG 2010. Lecture Notes in Computer Science (pp. 321-336). Berlin: Springer-Verlag. Retrieved from https://doi. org/10.1007/978-3-642-15714-1_24

Ferreira, G.C.L., Silveira, P.S., Noto, A.R., \& Ronzani, T.M. (2014). Implicações da relação entre estigma internalizado e suporte social para a saúde: uma revisão sistemática da literatura. Estudos em Psicologia (Natal), 19(1), 77-86. https://doi. org/10.1590/S1413-294X2014000100010

Gibson, L. Moncur, W., Forbes, P., Arnott, J., Martin, C., \& Bhachu, A. S. (2010). Designing social networking sites for older adults. In Proceedings of the 24th BCS Interaction Specialist Group Conference (pp. 186-194). Dundee, UK: British Computer Society. Retrieved from https://dl.acm.org/ citation.cfm?id $=2146331$.

Grieve, R., Indian, M., Witteveen, K., Tolan, G. A., \& Marrington, J. (2013). Face-toface or Facebook: Can social connectedness bederived online? Computers in Human Behavior, 29(3), 604-609. https://doi.org/1 0.1016/j.chb.2012.11.017

Griep, R. H., Chor, D., Faerstein, E., Werneck, G. L., \& Lopes, C. S. (2005). Validade de constructo de escala de apoio social do Medical Outcomes Study adaptada para o português no Estudo Pró-Saúde. Cadernos de Saúde Pública, 21 (3), 703-714. https://do i.org/10.1590/S0102-311X2005000300004

Kahn, R. L. \& Antonucci, T. C. (1980). Convoys over the life-course: Attachment, roles and social support. In P. B. Baltes \& O. G. Brim (Eds.), Lifespan development and behaviour (pp. 253-286). New York, NY: Academic Press. Retrieved from http://agris.fao.org/agris-search/searc h.do? recordID $=$ US201302069551.

Lampert, S. S. (2009). Rede de apoio social, resiliência e marcadores imunológicos em idosos cuidadores de pacientes com demência (Dissertação de Mestrado). Instituto de Geriatria e Gerontologia, Pontifícia Universidade Católica do Rio Grande do Sul, Porto Alegre. Retrieved from http://hd 1.handle.net/10923/3603

Myhre, W. J., Mehl, M. \& Glisky, E. (2016). Cognitive benefits of online social networking for healthy older adults. The Journals of Gerontology Series B, 72(5), 752-760. https://doi.org/10.1093/geronb/gb w025

Neri, A. L. (2014). Redes de Suporte Social. In A. L. Neri (Eds.), Palavras-chave em gerontologia (pp. 289-295). São Paulo: Alínea.

Páscoa, G., \& Gil, H. (2012). O facebook e os idosos: a importância do software social na aprendizagem ao longo da vida. In $7^{a}$ Conferencia Ibérica de Sistemas Y Tecnologías de Información (pp. 544-549). Madrid: AISTI - UPM. Retrieved from htt p://hdl.handle.net/10400.11/1346

Paula-Couto, M. C. P., Koller, S. H., Novo, R., \& Soares, P. S. (2008). Adaptação e utilização de uma medida de avaliação da rede de apoio social - diagrama da escolta - para idosos brasileiros. Universitas Psychologica, 7(2), 493-505. Retrieved from http://revistas.javeriana.edu.co/index. php/revPsycho/article/view/493

Rodrigues, A. G. \& Silva, A. A. (2013). A rede social e os tipos de apoio recebidos por idosos institucionalizados. Revista Brasileira de Geriatria e Gerontologia, 16(1) 159-170. https://doi.org/10.1590/S18 09-98232013000100016

Rodrigues, A. G. (2010) Habilidades comunicativas e a rede social de apoio de idosos institucionalizados (Tese de Doutorado). 
Instituto de Psicologia, Universidade de São Paulo, São Paulo. Retrieved from http://www.teses.usp.br/teses/disponi veis/47/47132/tde-02052011-141852/publi co/rodrigues do.pdf.

Rosa, T. E. C., Benício, M. H. D., Alves, M. C.G.P., \& Lebrão, M. L. (2007). Aspectos estruturais e funcionais do apoio social de idosos do Município de São Paulo, Brasil. Cadernos de Saúde Pública, 23(12), 2982-2992. http://dx.doi.org/10.1590/S010 2-311X2007001200019

Santiago, D. R. P. (2011) Inclusão digital: estratégia de co-participação de idosos no lazer virtual (Tese de Doutorado). Instituto de Biociências do Campus de Rio Claro, Universidade Estadual Paulista, São Paulo. Retrieved from https://repositorio.unesp.br/ bitstream/handle/11449/104675/santiago drp_dr_rcla.pdf? sequence $=1$ \&isAllowed $=\mathrm{y}$

Sherbourne, C. D., \& Stewart, A. L., (1991). The MOS social support survey. Social Science Medicine, 32(6), 705-14. https://doi.org/10. 1016/0277-9536(91)90150-B

Sousa, A. I., Silver, L.D., \& Griep, R. H. (2010). Apoio social entre idosas de uma localidade de baixa renda no Munícipio do Rio de Janeiro. Acta Paulista de Enfermagem, 23(5), 625-631. https://doi.org/10.1590/S0103-21 002010000500007.

Zickurh, K. \& Madden, M. (2012). Older adults and internet use. (Pew Internet \& American Life Project). Washington D.C.: Pew Research Center. Retrieved from http://www.pewinternet.org/2012/06/ 06/older-adults-and-internet-use/

\section{Notes}

* Research article. 